\title{
Questionnaire Survey Focused on the Quality of the Working Environment of Industrial Plants: Case Study
}

\author{
Miriama Piňosová
}

\section{ABSTRACT}

\begin{abstract}
There are different views on questionnaire surveys among researchers. Some experts question their use in the scientific field because of great subjectivity. However, using the current scientific methods of creating questionnaires, respondent's selection, surveying itself and, in particular, evaluating, we can achieve interesting results that can then be verified by other, more suitable methods. The basic idea behind creating a questionnaire was to find out in what working conditions the respondents work and what desired or undesired impacts they are exposed to during their work. We have processed this questionnaire so that it is suitable for all types of operations and for all types of workplace factors. When designing the individual questions of the questionnaire, we tried not to deviate from the relation between the questions and the studied issue. We tried to formulate the questions in a clear way so that they would not be interpreted as obscure or ambiguous. The questions were not suggestive, and rather served as guidelines without suggesting any specific answers. We also tried to ask questions that would not require certain knowledge or information that respondents did not have.
\end{abstract}

Keywords: Data Analysis, Environmental Quality, Health, Industry, Work, Questionnaire.

\section{INTRODUCTION}

Quality of the working environment is one of the most important factors affecting the performance of employees, their well-being, reduced workload, reducing errors, incapacity for work, or the emergence of occupational diseases. Achieving the right balance in workplaces is not always easy. The industrial work environment is generally affected by one or more undesirable influences.

An integral part of the philosophy of sustainable development is the focus on improving the quality of life, especially work life. The value of one's health, comfort at home and at the workplace are coming to the forefront. Work and the workplace are important determinants of the health of an individual and society. In addition to the positive impact, one's workplace may also have a negative impact, ranging from insignificant changes (professional stigmas) through more severe changes (occupational diseases) to fatal cases.

Even though scientific and technological developments have in many cases brought about a substantial improvement in working conditions, however, employees are exposed to noise, a variety of pollutants, vibrations, electromagnetic radiation, and the like even today. All these workplace parameters have a significant impact on people and are therefore regulated by legislation that lists limit values and above limit values regarding individual components of the workplace. In order to ensure optimal conditions, quality measurement technology and sophisticated methods of quality assessment of the workplace are used.
The constantly changing world brings to the workplace new risks related to activities carried out by employees. It should be noted that many of the risks present at the workplace have existed since the industrial revolution but failed to be sufficiently addressed. Damage to employees' health was not, at that time, attributed to the quality of the workplace. In line with EU-OSHA's (European Agency for Safety and Health at Work) strategy to improve safety and health at work as well as instructions of EU-OSHA's European Risk Observatory, EU Member States are urged to increase their efforts in identifying health risks at work.

The issue of assessing the impact of environmental factors (in particular, the problem of complex quality assessment of the workplace) on human health is insufficiently promoted in the Slovak Republic. Many authors have dealt with the evaluation of the quality of the work environment and the assessment of the negative effects of physical factors in the work environment on the health of employees [1]-[7]. In her work, Seňová [8] used the point evaluation method to assess the risk of working professions in the quarry. Hnilica [9] focused its attention on the selection of methods by which it would be possible to comprehensively assess the effects of risk factors of the work environment on humans. Like Seňová, Hnilica points to the possibility of using the point method for evaluating risk factors in the work environment. As another option, he chose the questionnaire method, which belongs to the subjective evaluation methods. Hrušková [10] states that the problematic hearing damage from noise in the automotive industry is not given enough attention. She drew 
attention to the need to carry out initial LPP before starting work, with appropriate documentation of exposure to the risk factor of work from the past. Hnilica [11] tries to outline the possibility of using multi-criteria decision-making methods in a comprehensive assessment of the quality of the working environment in terms of work risk. The case study focused on four risk factors (noise, temperature, vibration, and mental strain) that have the most significant impact on the health of forestry operators. To evaluate these physical factors, he chose the Saaty method (analytical hierarchical process). Using the methods of mathematical statistics, Kapustová [12] developed an original mathematical model, which allows to express the total effect of negative environmental factors and to evaluate the complex load of the human body during the observed working hours.

\section{Characteristics OF THE WORKING ENVIRONMENT}

The huge development of science and technology has brought new technologies, new business processes, the possibility to explore the unknown, introduce newer and more modern machinery and technologies, automated processes, and also new job opportunities.

With these advances and the introduction of new technologies, a new and yet-unknown risk began to emerge. The working process now entails more work factors that are becoming increasingly difficult to identify, objectify or assess.

Qualitative and quantitative assessment requires new modern measuring equipment, the best laboratories, and competent personnel for its implementation. In order to eliminate or reduce harmful factors of work and the working environment to the lowest level possible it is necessary to adopt a variety of technological, technical, organizational and other measures. Despite the adoption of these measures, the workplaces feature physical, chemical, biological and other factors in excess of permissible limits, and their effects can adversely affect the health of employees.

In order to prevent potential harm to health, it is important to know all the adverse factors that occur in the workplace, i.e., identify them, objectify them, ensure their qualitative and quantitative assessment, draw up reports on risk categorization and take measures to reduce them.

In the working and outside environment, a single factor is never found by itself, rather there are always a number of factors the effects of which can be combined, multiplied and thereby adversely affect the human body [6]. For the assessment of any harmful agents present in the working environment, it is important to know the adverse effects of each one of the present factors and the ways they enter the body, which parts of the body they can damage, what difficulties they may cause, symptoms they can cause, and many others [13]-[15].

Evaluating and assessing health risks at work due to exposure to harmful workplace factors and the working environment is a challenging and long-term process. Limit values are defined for the categorization of types of work in such a way that it is not foreseeable that, according to current scientific knowledge, they will be detrimental to the health of employees. However, these limit values are set for each factor alone and do not take into account the effect of the combined action of individual factors on the human body [16].

Currently, the effect of environmental factors is most frequently assessed by comparing the individual with determining the actual (permissible or recommended) value.

Values of working environment factors can be determined by calculation, measurement, or a reliable estimate. The optimum values for the working environment are given by standards, legislation, health regulations, or professional literature. Permissible (maximum and minimum) values of working environment factors are usually determined by calculation (using the correction coefficients) of the basic (optimal) values.

\section{A. Illnesses and Other Occupational Harm to Health in Slovakia 1987-2019}

Even now, there are cases of neglect in the area of protecting health against occupational diseases. On the one hand, this occurs with employers who do not comply with legislation and ignore the topic, thereby underestimating the risk of illness among their employees. On the other hand, this is due to the employees themselves, gambling with their health in order to keep their jobs, regardless of the consequences [17]. The method of reporting and recording occupational disease and the threat of occupational disease is defined in the Slovak Republic by Section 31(b) $(1,2)$ of Act no. 355/2007.

Based on data documented by the National Health Information Centre (NHIC), a total of 21045 new occupational diseases were reported in Slovakia during 19872019. A significant decrease in the number of reported occupational diseases was recorded up to 1995, from 1262 (1987) with a slight increase to 1331 (1990) then down to 601 (1995). Between 1995 and 2019, the number of newly acquired occupational diseases decreased by roughly half, with moderate variation, to 347 (2019), with the lowest ever number in 2013 (301). Alongside the significantly decreasing trend in the number of reported occupational diseases, there was a gradual increase in the proportion of women among the number of reported occupational diseases since 2003. Since 2010 , the total number of reported occupational diseases in men and women has decreased in parallel, with stronger increases in men in 2014 (244) and 2017 (207) see Fig. 1.

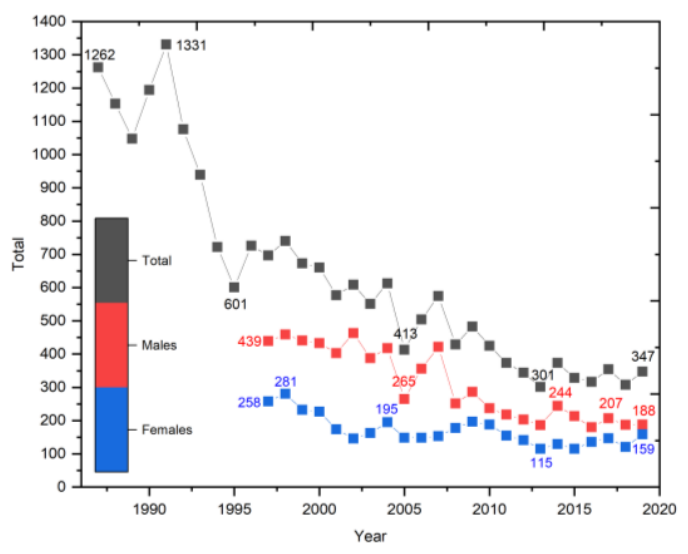

Fig. 1. Development of occupational diseases in years 1987-2019 in the Slovak Republic in Males and Females.

Analysis of occupational diseases reported over the last 32 years (1987-2019) shows a more significant decrease in the 
number of reported occupational diseases in the second half of the reporting period (2003-2019) of 49.76\%, i.e., 6971 cases. Compared to the period from 1987 to 2002, we can observe a decrease of $35.61 \%$ ( 713 cases) in diseases of the bones, joints, muscles, blood vessels and nerves in the extremities caused by work with vibrating tools (item 28). Conversely, a stronger increase is observed in occupational diseases affecting the musculoskeletal system, the circulatory and nervous systems of workers exposed to prolonged excessive and one-sided upper limb loads of $55.58 \%$, i.e., 3065 cases in women (item 29), and additional results are listed on Fig. 2 and Table 1.

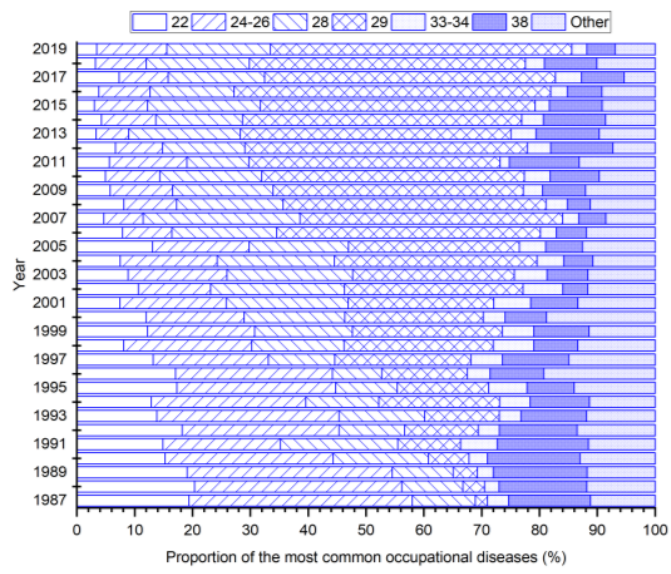

Fig. 2. Development of occupational diseases in years 1987-2019 in the Slovak Republic.

TABLE I: COMPARISON OF OCCUPATIONAL DISEASES REPORTED IN THE

\begin{tabular}{cccccc}
\multicolumn{7}{c}{ LAST 32 YEARS } \\
\hline \hline $\begin{array}{c}\text { Disease } \\
\text { number }\end{array}$ & Total & $\begin{array}{c}1987- \\
2002\end{array}$ & $\begin{array}{c}2003- \\
2019\end{array}$ & Decrease/increase & $\% *$ \\
\hline Total all & 21045 & 14008 & 7037 & -6971 & 49.76 \\
22 & 2565 & 2125 & 440 & -1685 & 79.29 \\
$24-26$ & 4516 & 3750 & 766 & -2984 & 79,57 \\
28 & 3291 & 2002 & 1289 & -713 & 35.61 \\
29 & 5035 & 1970 & 3065 & +1095 & 55.58 \\
$33-34$ & 895 & 637 & 258 & -379 & 59.50 \\
38 & 2197 & 1684 & 513 & -1171 & 69.54 \\
\hline \hline
\end{tabular}

Explanation: * decrease or increase in percentage for the second half of the reference period compared to 1987-2002, (22) Occupational dermatoses - Skin diseases apart from skin cancer and communicable skin diseases. (24) Diseases on communicable and parasitic illnesses apart from tropical communicable and parasitic diseases and illnesses communicable from animals on people. (25) Tropical communicable and parasitic diseases. (26) Illnesses communicable from animals on people directly or by means of communicants. (28) Vibration disease - Diseases of bones, joints, muscles, vessels, and nerves limbs caused at work with vibrating tools and device. (29) Diseases of bones, joints, tendons, and nerves of limbs from long-term, inordinate, one-sided workload. (33) Diseases on dusting of lung with dust containing silicon oxide (silicosis, silicotuberculosis) including (miner pneumoconiosis) - a) with typical x-ray signs take account on dynamics of diseases; b) in connection with active tuberculosis. (34) Diseases on dusting of lung with asbestos dust (Asbestosis) - a) with typical x-ray signs; b) in connection with lungs cancer. (38) Hearing defect from noise by which is reached loss hearing according to Fowler with harm younger as 30 years at least $40 \%$. Harm older as 30 years then presented level is increased by $1 \%$ each two years until 50 years age of harm person and since that time loss hearing must exceeded $50 \%$; the other ones are Annex no. 1 to Act no. 461/2003 Coll., on social insurance.

The authors in other publications [13], [17]-[19] have addressed the analysis of occupational diseases and the system of categorization of work in relation to health protection at work in the Slovak Republic and in the Czech Republic. A large number of authors [22]-[24] have evaluated the quality of the work environment and assessed the negative impacts of physical factors in the working environment on the health of employees.

\section{MATERIALS AND METHODS}

\section{A. The Purpose of the Research}

The questionnaire survey is always based on the requirement of a particular entity. This entity can be essentially anyone, but most often a scientific group or an individual. Typically, these entities need to find a response to a question that might help with solving their problem. The outputs that each survey can provide are always derived or calculated from the accumulated data. In case of a questionnaire survey quantitative methods are applied on the data expressing the opinion of individual respondents. Provided there is a sufficient representative sample, views of participants can be generalized using statistical selection methods. The results of the questionnaire survey serve mostly as the baseline assumptions which are subsequently confirmed by other methods [25].

\section{B. Data Preparation for Statistical Analysis}

The quality of the data obtained is reduced by the existence of errors that occur during the research. We tried to minimize these errors, however. The most common causes of errors are unfit responses, errors in recording responses and failure to identify the answers. Unfit answers arise especially when respondents misunderstood the questions asked, when the answer is incomplete, when answers are illogical and the like. The errors occurred both during data collection and during the processing phase as well. Other causes affecting data quality are directly dependent on the respondent and his/ her willingness or ability to respond. If a respondent does not understand the question or the offered answers fail to capture the required information, such an answer cannot be included. This is also the case if the respondent refuses to answer, either because of a sensitive nature of the topic, lack of time, fear the responses are not anonymous, other complications, and the like.

\section{Objective, Subject Matter and Tasks of the Research}

Objectively: determine the impact of negative factors of the workplace on human health. Evaluate the possibility of using the questionnaire survey in practice following the validation of the results. Subject matter: employees' views on the quality of their workplace and subjective feelings about their health in relation to factors that have an impact on their work. Tasks: in order to achieve the set objective, we considered it necessary to carry out the following tasks:

1) Determine what negative workplace factors influence employees.

2) Find out what health issues these factors cause employees.

3) Compare the results of the questionnaire with real clinical symptoms (currently running).

\section{Methodology of the Questionnaire Survey}

In the preparatory phase we focused on analyzing the available information on the physical factors of the workplace and their impact on health. We used logical methods (analysis, synthesis, induction, deduction, comparison). At 
this stage, we also focused on the preparation of the project. We set our goal, outlined the subject matter, tasks and hypotheses.

In the implementation phase we focused on the acquisition of empirical facts and used the exploration method in a twostage questionnaire survey: Pre-research "quality test": was performed to confirm the correctness of the formulation of the questionnaire (whether or not the respondents understand the questions). The questionnaire was submitted to the employees of the Technical University in Košice, who were not part of our sample. Final version of the questionnaire: based on the conclusions of the pre-research we have changed some of the items and in some other we prepared additional explanations. The questionnaire contained 58 questions and was divided into eight units. The questionnaire consists of 46 closed questions, 6 open-end questions and 6 mixed questions. The questionnaire is based on the assumption that the anonymity of the questionnaire means more honest answers.

\section{E. Subject Matter of the Research}

The anonymous questionnaire survey was submitted to the employees who were exposed to various adverse workplace factors such as noise, vibrations, electromagnetic radiation, inappropriate lighting, hot/ humid microclimate, dust, etc. during working hours.

Description of the sample: from the planned sample of 180 employees the re-search was attended by 140 respondents, which means we have reached $77.77 \%$ return rate $(90$ men and 50 women). The return rate is defined as the ratio of the number of sent questionnaires to the number of completed and returned questionnaires.

Employees were divided into age categories (Table 2).

TABLE II: DisTRIBUTION OF THE SAMPLE BY AGE

\begin{tabular}{ccccccc}
\hline \hline Age category & Men & $\%$ & Women & $\%$ & Total & $\%$ \\
\hline$\leq 20$ & 1 & 0.71 & 0 & 0.00 & 1 & 0.71 \\
$21-30$ & 20 & 14.29 & 10 & 7.14 & 30 & 21.43 \\
$31-40$ & 52 & 37.14 & 24 & 17.14 & 76 & 54.29 \\
$41-50$ & 15 & 10.71 & 9 & 6.43 & 24 & 17.14 \\
$51+$ & 2 & 1.43 & 7 & 5.00 & 9 & 6.43 \\
\hline Total & 90 & 64.29 & 50 & 35.71 & 140 & 100.00 \\
\hline \hline
\end{tabular}

\section{F. Description of Employees' Activities}

The sample was made up of female and male employees of different ages and different job positions (packer, quality control employee, engineer, maintenance employee, office clerk, etc.) who work in the company the main activity of which is the production of products for intimate hygiene made of cellulose.

On the production line several major operations take place. The work cycle at the individual parts of the line depends on the type of activity being performed. Various technological operations are involved in the production - dividing, joining, pressing, cutting, and packing of products. The whole process of manufacturing hygienic products consists of several manufacturing steps. The raw material is placed on the conveyor belts where the pulverized cellulose is deposited into moulds. Transfer wheels then place it on the conveyor table where adhesive fixing is applied on the cellulose. Subsequently, the separated products are conveyed through conveyor belts to a stacking device which positions the products to fit into the packaging. Products packing takes place in the packaging machine. The packages are loaded by operators into the boxes. The last step is to move finished products to the warehouse.

There is a four-shift operation in this company. Over a week, up to 70 million pieces of products are produced. We can assume that employees are not affected by the negative factors at the beginning of their working hours because the workplace and relevant technical documentation, machine setup and planning usually take place. The similar situation arises at the end of the shift - personal hygiene, cleaning of the workplace, personal breaks.

\section{G. Outlining the Hypotheses}

In order to comprehensively assess the quality of the workplace through the questionnaire survey method based on the outlined objectives, tasks and the knowledge from the theoretical sources, we have outlined the following research hypotheses:

Hypothesis H1: there is a dependence between the job position and the occurrence of symptoms caused by factors present at the workplace.

Hypothesis H2: there is a dependence between gender and the occurrence of symptoms caused by factors present at the workplace.

Hypothesis H3: more than $85 \%$ of employees have problems due to high exposure to workplace noise.

Hypothesis H4: more than $60 \%$ of employees are aware of the health problems associated with their work.

Other criteria taken into account when evaluating the results of the questionnaire survey were the differences between women and men and also among the selected age groups of employees.

\section{INTERPRETATION OF RESEARCH RESULTS}

We analyzed the survey results according to the individual answers in the questionnaire, which were then divided into eight blocks according to the risk factors of the workplace. As this issue is quite extensive, we have only focused on the evaluation of selected issues. The criteria taken into account when evaluating the results of the questionnaire survey are the differences between genders and also between the age groups.

\section{A. General Requirements for the Workplace}

Employee responses indicate that 75 respondents, of which are 35 men $(25 \%)$ and 40 women $(28.57 \%)$ work manually. We divided the sample file into five age categories according to gender. The largest age group is formed by employees aged between 31 to 40 years. This group includes 76 respondents, of which $52(37.14 \%)$ are men and $24(17.14 \%)$ are women. The most respondents work as packers - 43 (30.71\%), mechanics $-36(25.71 \%)$ of whom is one female employee, and technicians $-31(22.14 \%)$. It is clear from the overall assessment of the workplace factors that the most employees interviewed consider noise to be the most disturbing factor 132 respondents $\mathbf{( 9 4 . 2 9 \% )}$ ) of which 83 are men and 49 women. Another alarming factor was the finding that 108 $\mathbf{7 7 . 1 4 \% )}$ respondents had problems with the exposure to solid aerosols and 90 employees had a problem with high air 
temperature (64.29\%). 95 respondents $(67.86 \%)$ denied having a problem with a bad smell at their workplace. Vibrations, light and cold seem to be problematic for about $45 \%$ of the respondents $( \pm 3 \%)$.

\section{B. Noise Nuisance at the Workplace}

To question Q1.B: Are there any noise sources at your workplace? up to 138 respondents $(98.57 \%)$ answered "yes".

Respondents were asked about the occurrence of symptoms that may be related to the exposure to noise at the workplace (Fig. 3). A significant majority of respondents $(73.91 \%)$ stated they have experienced a negative impact on their mental health, pointing out mainly fatigue, exhaustion and headaches, irritability, reduced concentration, low attention span, poor performance, etc. Respondents in the age group 31 to 40-years-olds were the largest group to complain (without gender differences). This group included 102 respondents, of whom $57(41.30 \%)$ were men and 45 $(32.61 \%)$ women. Approximately half of respondents have hearing problems. Approximately 63 (45.65\%) of respondents suffer from changes in blood pressure. Ear tingling, the so-called tinnitus was reported by an average of $58(42.03 \%)$ respondents, the other symptoms were less frequent.

\section{Occurrence of Solid Aerosols at the Workplace}

To question Q1.D: Are there any sources of dust at your workplace? up to 126 respondents $(90.00 \%)$ answered "yes".

$100(79.37 \%)$ respondents perceive the presence of fine dust at their workplace. Approximately 35 (27.78\%) respondents expressed dissatisfaction with the presence of dust in poorly ventilated areas of their workplace. However, it should be noted that according to this questionnaire survey employees do not use sufficient personal protective equipment (PPE) that the employer provides. Only one respondent said he was using a respirator at work, otherwise $125(99.21 \%)$ respondents said they were not using any PPE, which we consider to be an alarming issue. Only one respondent said his health was not compromised by dust in the air. A significant majority of respondents $(61.11 \%)$ said dust at the workplace has a negative impact on their health it mainly causes a problem with unproductive cough. This group included 77 respondents, of which 43 (34,13\%) were men and 34 (26,98\%) were women. The increased production of mucus and its subsequent expectoration was observed by $35(27.78 \%)$ respondents. Difficulties with breathing were reported by $28(22.22 \%)$ respondents, the other symptoms are less frequent. None of the respondents have a weight loss problem. The second most problematic factor of the workplace is dust, preceded only by noise (Fig. 3).

\section{Problem with Humidity and Thermal Conditions at the Workplace (Microclimate)}

To question Q1.F: Do you work at the workplace with unfavorable microclimatic conditions? up to 97 respondents $(69,29 \%)$ answered "yes".

About 50 (35.72\%) respondents expressed dissatisfaction with the humidity level at their workplace. High air humidity makes heat transfer difficult, thus causing problems with sweating and breathing. The relative air humidity should reach a maximum of $80 \%$. The airflow rate at the workplace was negatively evaluated by $33(23.58 \%)$ respondents. A significant majority of respondents, 83 (59.28\%), assessed the temperature of air unfavourably, stating that the temperature is too high in summer and too low in winter. Extreme temperatures during the summer may lead to a decrease in performance, can cause the body to overheat, drowsiness, headaches, dizziness, nausea, and vomiting. In this case, the water intake is very important. By drinking a person should replace at least $70 \%$ of the water lost during work due to excessive sweating and breathing. That is why the responds were asked "What is your water intake when working in hot climate?" 101 (72.14\%) of the respondents said they drink 2 litres of water when working in the hot environment. This is a bad thing because people working in such environments should drink at least 3 litres (or more) of water. Thanks to the previous findings which proved that the microclimatic conditions at the workplace negatively affect the health of employees working under such conditions, in particular air temperature $(59.28 \%)$, relative humidity $(35.72 \%)$ and air flow rate $(23.58 \%)$, we can say that the health problems related to work performed by employees are influenced by these negative influences (Fig. 3). Headaches were reported by $69(71.13 \%)$ respondents, total weakness by about $47(48.45 \%)$ respondents. However, dizziness $(17.53 \%)$ and nausea $(35.05 \%)$ experienced by employees may be due to insufficient water intake, as they only drink 2 litres of water during their working hours, which is in our opinion an insufficient amount. In the winter months, 39 $(40.21 \%)$ of respondents complain about rhinitis.

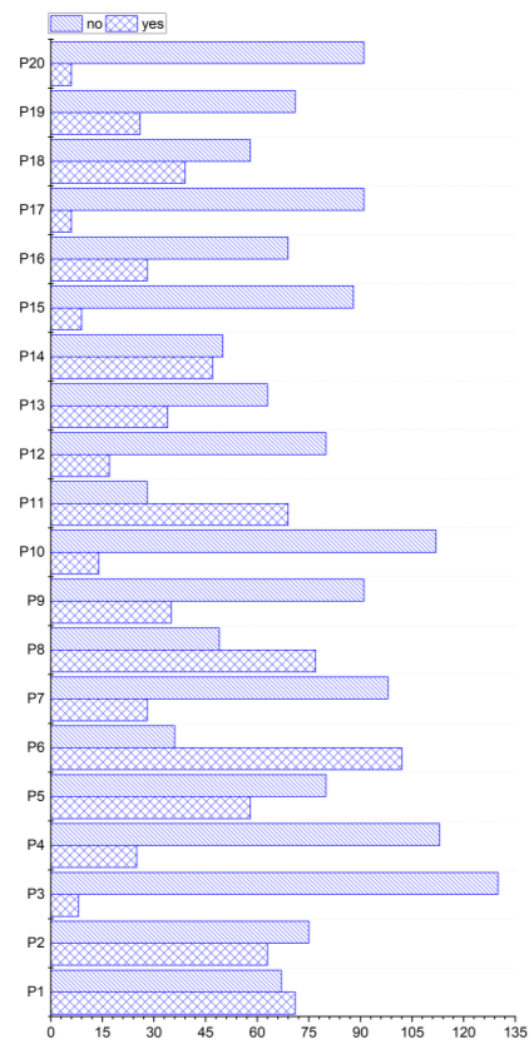

Fig. 3. Overall Assessment of the Occurrence of Symptoms. Explanation: P1 - Hearing loss, P2 - Blood pressure changes, P3 - Other cardiovascular diseases, P4 - Gastrointestinal disease, P5 - Tinnitus, P6 - Fatigue, exhaustion, headache, P7 - Difficulty breathing, P8 - Dry cough, P9 - Increased mucus production and its subsequent expectoration, P10 - Chest pain during physical activity, P11 - Headache, P12 - Dizziness, P13 - Nausea, P14 Weakness, P15 - Cramps due to salt loss, P16 - Breathing difficulties, P17 Frostbites, P18 - Rhinitis, P19 - Increased Temperature, P20 - Vomiting. 


\section{THE ANALYSIS OF THE DEPENDENCE BETWEEN THE VARIABLES “JOB POSITION” AND "OCCURRENCE OF SYMPTOMS"}

For the sake of simplicity, we categorized the employees into two core groups, namely: "TE (technical-economic) employees" - include the following job positions: office clerk, quality control employee, team leader; and "Laborer" include: packer, operator, engineer, technician, maintenance employee.

In the next step, we first tested the dependence between the two variables: "Job Position" (TE employee, Laborer) and "Occurrence of the Observed Symptoms" (hearing loss, changes in blood pressure, heart disease, gastrointestinal disease, tinnitus, fatigue, exhaustion, and headache) - in case of noise; (dry cough, breathing difficulties, chest pain, increased mucus production) - in case of solid aerosols; (headache, dizziness, general weakness, spasms due to loss of salt, breathing difficulties, frostbites and burns, rhinitis, increased temperature and vomiting) - in case of microclimate.

In the next step, we first tested the dependence between the two variables: "Job Position" and "Hearing Loss". In both cases, there are nominal variables with two possibilities (categories) that we call dichotomic.

At the level of significance $\alpha$ we tested the null hypothesis $H_{0}$ the variables are independent against the alternative hypothesis $H_{1}$ variables are dependent. We reject the null hypothesis $H_{0}$ at the level of significance $\alpha$ if the value of the test variable $\chi^{2}$ is greater than $1-\alpha$ quantile $\chi^{2}$ of division with one degree of freedom. In order to verify the hypothesis, we used $\chi^{2}$ - independence test (Pearson's independence test). According to the Pearson's independence test the test value of the variable is equal to 5.570 . The critical value is 3.841 . We reject the zero hypothesis at the level of significance $\alpha=0.05$, which means that we can assume that there is a certain dependence between the variable "Job Position" and the "Hearing Loss".

TABLE III: TEST RESULTS “JOB POSITION" VS. "OBSERVED SYMPTOMS”

\begin{tabular}{|c|c|c|c|c|c|c|}
\hline Sym. & $x^{2}$ & $\chi_{1-\alpha}^{2}$ & $\chi^{2}>\chi_{1-\alpha}^{2}$ & Q & V & $\mathrm{C}_{\mathrm{p}}$ \\
\hline P1 & 5.570 & \multirow{20}{*}{3,841} & + * & -0.385 & -0.200 & 0.196 \\
\hline $\mathrm{P} 2$ & 0.355 & & - & 0.101 & 0.050 & 0.050 \\
\hline $\mathrm{P} 3$ & 0.881 & & - & 0.333 & 0.079 & 0.079 \\
\hline $\mathrm{P} 4$ & 0.380 & & - & 0.135 & 0.052 & 0.052 \\
\hline P5 & 5.682 & & + * & -0.396 & -0.201 & 0.197 \\
\hline P6 & 0.807 & & - & -0.169 & -0.076 & 0.076 \\
\hline P7 & 7.384 & & + 粦 & -0.559 & -0.242 & 0.235 \\
\hline P8 & 2.916 & & - & -0.304 & -0.152 & 0.150 \\
\hline P9 & 1.128 & & - & -0.211 & -0.095 & 0.094 \\
\hline P10 & 4.331 & & $+*$ & -0.583 & -0.185 & 0.182 \\
\hline P11 & 4.150 & & $+*$ & -0.476 & -0.207 & 0.202 \\
\hline $\mathrm{P} 12$ & 0.083 & & - & -0.078 & -0.029 & 0.029 \\
\hline P13 & 4.112 & & $+*$ & -0.425 & -0.206 & 0.202 \\
\hline P14 & 0.021 & & - & -0.029 & -0.015 & 0.015 \\
\hline P15 & 0.005 & & - & 0.026 & 0.007 & 0.007 \\
\hline P16 & 4.224 & & $+*$ & -0.451 & -0.207 & 0.203 \\
\hline P17 & 0.117 & & - & 0.143 & 0.035 & 0.035 \\
\hline P18 & 4.515 & & $+* *$ & 0.427 & 0.216 & 0.211 \\
\hline P19 & 0.014 & & - & -0.027 & -0.012 & 0.012 \\
\hline P20 & 0.117 & & - & 0.143 & 0.035 & 0.035 \\
\hline
\end{tabular}

Explanation: + dependent, - independent, * TE employee, $*$ Laborer.
The strength of the dependence between the dichotomic variables is expressed by the following coefficients: the association coefficient $\mathrm{V}$, the Pearson coefficient of contingency $C_{p}$ and the Yule coefficient Q. Yule coefficient $(\mathrm{Q}=-0.385)$, the association coefficient $(\mathrm{V}=-0,200)$ and the Pearson coefficient of contingency $\left(C_{p}=0,196\right)$. The coefficients confirm the very slight dependence between the variables studied. The association coefficient shows that dependence is indirect. To determine how the symptom hearing loss was affected by the job position we used a percentage difference. This shows that the number of TE employees with hearing loss is lower (by 20\%) than the number of Laborer with hearing loss.

Analogously, we tested the dependence between the "Job Position" and others the "Observed Symptoms". The results are shown in Table 3., resp. "Gender" and "Observed Symptoms" see Table 4.

TABLE IV: TEST RESULTS “GENDER” VS. "OBSERVED SYMPTOMS”

\begin{tabular}{|c|c|c|c|c|c|c|}
\hline Sym. & $\chi^{2}$ & $\chi_{1-\alpha}^{2}$ & $\chi^{2}>\chi_{1-\alpha}^{2}$ & Q & V & $\mathrm{C}_{\mathrm{p}}$ \\
\hline P1 & 0.336 & \multirow{20}{*}{3,841} & - & -0.102 & -0.049 & 0.049 \\
\hline $\mathrm{P} 2$ & 2.545 & & - & 0.280 & 0.135 & 0.134 \\
\hline P3 & 0.754 & & - & -0.303 & -0.073 & 0.073 \\
\hline P4 & 2.000 & & - & -0.303 & -0.119 & 0.118 \\
\hline P5 & 3.936 & & $+a$ & -0.335 & -0.168 & 0.166 \\
\hline P6 & 11.558 & & $+a$ & -0.678 & -0.287 & 0.276 \\
\hline P7 & 2.827 & & - & -0.347 & -0.150 & 0.148 \\
\hline P8 & 4.996 & & $+a$ & -0.418 & -0.199 & 0.195 \\
\hline P9 & 0.008 & & - & -0.019 & -0.008 & 0.008 \\
\hline P10 & 5.859 & & $+\infty$ & 0.794 & 0.216 & 0.211 \\
\hline P11 & 1,654 & & - & -0.292 & -0.131 & 0.129 \\
\hline P12 & 2.315 & & - & -0.386 & -0.154 & 0.153 \\
\hline P13 & 5.880 & & $+\bullet$ & -0.481 & -0.246 & 0.239 \\
\hline P14 & 0.127 & & - & 0.073 & 0.036 & 0.036 \\
\hline P15 & 0.324 & & - & 0.206 & 0.058 & 0.058 \\
\hline P16 & 0.279 & & - & -0.118 & -0.053 & 0.053 \\
\hline P17 & 0.209 & & - & 0.200 & 0.046 & 0.046 \\
\hline P18 & 0.387 & & - & 0.130 & 0.063 & 0.063 \\
\hline P19 & 0.219 & & - & -0.108 & -0.048 & 0.048 \\
\hline $\mathrm{P} 20$ & 0.157 & & - & -0.165 & -0.040 & 0.040 \\
\hline
\end{tabular}

Explanation: + dependent, - independent, $\boldsymbol{\vee}$ woman, $\uparrow$ man.

\section{CONCLUSION}

A conclusion section is not required. Although a conclusion may review the main points of the paper, do not replicate the abstract as the conclusion. A conclusion might elaborate on the importance of the work or suggest applications and extensions.

The anonymous questionnaire was designed to test the established hypotheses. The results obtained after the statistical evaluation of the case study can be summarized in the following statements.

We assumed the following hypotheses:

Hypothesis H1: There is a dependence between variables job position and the occurrence of symptoms caused by factors of the workplace. This hypothesis was confirmed / not confirmed in the following cases:

Noise

There is a dependence between variables job position and the occurrence of hearing loss (P1), resp. tinnitus (P5). There is no dependence between variables job 
position and the occurrence of the change in blood pressure (or cardiovascular disease, gastrointestinal disease, fatigue, exhaustion, and headache).

$\underline{\text { Solid aerosols }}$

There is a dependence between variables job position and the occurrence of breathing difficulties (P7), resp. chest pain (P10). There is no dependence between variables type of job position and the occurrence of dry cough, increased mucus production and subsequent expectoration.

\section{Microclimatic conditions}

- There is a dependence between variables job position and the occurrence of headache (P11), resp. nausea (P13); breathing difficulties (P16); rhinitis (P18). There is no dependence between variables job position and the occurrence of dizziness, general weakness, cramps due to salt loss, frostbite, increased temperature, vomiting.

Hypothesis H2: There is a dependence between variables gender and the occurrence of symptoms caused by factors present at the workplace. This hypothesis was confirmed / not confirmed in following cases:

$\underline{\text { Noise }}$

- There is a dependence between variables gender and tinnitus (P5), resp. fatigue, exhaustion, headaches (P6). There is no dependence between variables gender and change in blood pressure, cardiovascular disease, digestive system diseases, and hearing loss.

$\underline{\text { Solid aerosols }}$

- There is a dependence between variables gender and dry cough (P8), resp. chest pain (P10). There is no dependence between variables gender and difficulty breathing, increased mucus production and its subsequent expectoration and weight loss.

\section{Microclimatic conditions}

- There is a dependence between variables gender and nausea (P13). There is no dependence between variables gender and headaches, dizziness, general weakness, cramps due to salt loss, breathing difficulties, frostbite, rhinitis, increased temperature, vomiting.

Hypothesis H3: more than $85 \%$ of employees have problems with loud noise at the workplace. This hypothesis has been confirmed. Until 138 respondents (98.57\%) report problems with exposure to loud workplace noise.

Hypothesis H4: on average more than $60 \%$ of employees are aware of the health problems associated with their work. This hypothesis has been confirmed. 89 respondents $(63.57 \%)$ indicate that they are aware of the health problems associated with their work.

We would like to point out that the results of the survey are based on responses of employees working in one company. The results of this research therefore cannot be generalized. In particular, we wanted to point out the possibilities, ways, and methods of addressing this issue.

\section{ACKNOWLEDGMENT}

The work presented in this paper was supported by the Project KEGA 032TUKE-4/2018.

\section{REFERENCES}

[1] L. Ševčíková, Hygiene - Environmental Medicine. Bratislava, 2011.

[2] I. Dianat, A. Vahedi, and S. Dehnavi, "Association between objective and subjective assessments of environmental ergonomic factors in manufacturing plants," Int. J. Ind. Ergon., vol. 54, pp. 26-31, 2016, doi: 10.1016/j.ergon.2015.12.004.

[3] D. Gavhed and A. Toomingas, "Observed physical working conditions in a sample of call centres in Sweden and their relations to directives, recommendations and operators' comfort and symptoms," Int. J. Ind. Ergon., vol. 37, pp. 790-800, 2007, doi: 10.1016/j.ergon.2007.06.006.

[4] E. Lumnitzer, M. Piňosová, and B. Hricová, Metodológia komplexného hodnotenia zdravotných rizik v priemysle 1, 1. Zręcin Zręcin: MUSKA sp. z o.o., 2015.

[5] M. Piňosová, E. Lumnitzer, and M. Andrejiová, “Analýza závislosti medzi pracovnou pozíciou a výskytom sledovaných zdravotných problémov v podmienkach priemyselného podniku s expozíciou hluku a vibrácií metódou dotazníkového šetrenia," in Nové trendy akustického spektra: vedecký recenzovaný zborník, 2012, pp. 151156.

[6] E. Lumnitzer, M. Piňosová, M. Andrejiová, and B. Hricová, Metodológia komplexného hodnotenia zdravotných rizík v priemysle 2, 1. Zręcin: Zręcin: MUSKA sp. z o.o., 2013.

[7] M. Andrejiová, M. Piňosová, and E. Lumnitzer, "The determination of negative influence of physical factors of working environment on human health by the Saaty method" Prac. Lek., vol. 69, no. 3-4, pp. 78-87, 2017.

[8] A. Seňová, P. Slaninová, and E. Weiss, "Evaluation of risk by point method for selected carrer in mining industry," Acta Montan. Slovaca, vol. 13, no. 2, pp. 278-284, 2008.

[9] R. Hnilica, "Synergy effect of risk factors in working environment and methods their assessment," Acta Fac. Tech., vol. 17, no. 2, pp. 25-34, 2012.

[10] M. Hrušková, J. Buchancová, M. Strýčková, J. Zibolenová, Š. Zelník, and H. Hudečková, "Sledovanie a hodnotenie zdravotného stavu zamestnancov vo vybraných prevádzkach automobilového priemyslu," Prac. Lek., vol. 67, no. 3-4, pp. 86-91, 2015.

[11] R. Hnilica, M. Jankovský, M. Dado, V. Messingerová, M. Schwarz, and D. Veverková, "Use of the analytic hierarchy process for complex assessment of the work environment," Qual. Quant., vol. 51, no. 1, pp. 93-101, 2017, doi:10.1007/s11135-015-0296-8.

[12] M. Kapustová, "Aplikácia matematických metód pri ekologizácii pracovného prostredia v strojárskych prevádzkach,” Mater. Sci. Technol., no. 2, pp. 1-5, 2004

[13] J. Buchancová, V. Švihrová, H. Hudečková, Š. Zelník, and T. Záborský, "Analýza profesionálnych ochorení na Slovensku za roky 2005-2014 aj z aspektu kategórií rizikových prác," Prac. Lek., vol 68, no. 1-2, pp. 23-32, 2016.

[14] J. a kol Buchancová, Pracovné lekárstvo a toxikológia, 1. slovens. Martin: Osveta, 2003.

[15] J. Buchancová et al., "Contribution to Occupational Angiopathy Diagnosis Using Special Examination Methods," Cent. Eur. J. Public Health, vol. 4, no. 1, pp. 26-32, 1996.

[16] M. Piňosová, M. Andrejiová, and E. Lumnitzer, "Analyzing clinical symptoms of the synergy of high exposure to noise and vibration on human health in productions," Prac. Lek., vol. 64, no. 2, 2012.

[17] L'. Legáth, "Choroby z povolania V SR z pohl'adu klinického pracovného lekárstva," Prac. Lek., vol. 62, no. 4, pp. 184-189, 2010.

[18] J. Bubeníčková, "Přehled profesionálních onemocnění z vibraci hlášených v Královéhradeckém kraji v letech 1997-2006 a úloha závodní preventivní péče," Prac. Lek., vol. 60, no. 3, pp. 99-105, 2008.

[19] A. Šplíchalová and K. Hrnčíř, "Systém kategorizace prací ve vztahu k ochraně zdraví při práci," Prac. Lek., vol. 63, no. 3-4, pp. 131-136, 2011.

[20] J. Buchancová, V. Švihrová, H. Hudečková, Š. Zelník, and T. Záborský, "Analýza profesionálnych ochorení na Slovensku za roky 2005-2014 aj z aspektu kategórií rizikových prác," Prac. Lek., vol 68, no. 1-2, pp. 23-32, 2016.

[21] A. Šplíchalová and K. Hrnčíř, "Systém kategorizace prací ve vztahu k ochraně zdraví při práci,” Prac. Lek., vol. 63, no. 3-4, pp. 131-136, 2011.

[22] S. Kirin and B. Šimić, "Employee satisfaction survey in hotel industry | Psihosocijalni čimbenici na radnom mjestu i zadovoljstvo radnika u hotelijerstvu," Sigurnost, vol. 62, no. 1, pp. 1-10, 2020, doi: 10.31306/s.62.1.6.

[23] M. Kundić and N. Smajla, "Impact of employee shareholding on workplace safety | Utjecaj radničkog dioničarstva na sigurnost i zaštitu na radnom mjestu," Sigurnost, vol. 62, no. 2, pp. 127-137, 2020, doi: 


\subsection{6/s.62.2.5.}

[24] D. A. Coelho, "Social, cultural and working conditions determinants of fatal and non-fatal occupational accidents in Europe | Društveni, kulturni i radni uvjeti kao determinante nesreća sa smrtnim i nesmrtnim posljedicama u Europi," Sigurnost, vol. 62, no. 3, pp. 217237, 2020.

[25] H. Řezanková, Analýza dat z dotazníkových šetrení, 3rd ed. Praha: Professional Publishing, 2011 